\title{
Impact of preoperative immunonutrition on thrombocyte phagocytic activity and early postoperative outcomes in invasive gastric cancer patients.
}

\section{Zbigniew Kamocki ( $\sim$ zkamocki@gmail.com )}

Uniwersytet Medyczny w Bialymstoku https://orcid.org/0000-0002-4414-9304

Joanna Matowicka

Uniwersytet Medyczny w Bialymstoku

Anna Jurczuk

Uniwersytet Medyczny w Bialymstoku

Anna Milewska

Uniwersytet Medyczny w Bialymstoku

Anna Kamocka

Imperial College London Faculty of Medicine

Boguslaw Kedra

Uniwersytet Medyczny w Bialymstoku

Research article

Keywords: Gastric cancer, glutamine, nutritional status, blood platelets phagocytosis, gastrectomy, postoperative complications

Posted Date: February 12th, 2020

DOI: https://doi.org/10.21203/rs.2.23286/v1

License: (c) (i) This work is licensed under a Creative Commons Attribution 4.0 International License. Read Full License 


\section{Abstract}

Background:The aim was to determine the phagocytic activity of thrombocytes in patients with gastric cancer and to assess the effect of oral and parenteral preoperative glutamine-based immunonutrition on nutritional status, thrombocyte phagocytic activity and early postoperative outcomes.

Methods:Patients suffer from invasive gastric cancer had been treated with preoperative immunonutrition with glutamine and they were compared to patients without nutritional treatment. Nutritional status, percentage of weight loss and BMI were assessed. Levels of total protein, albumin, cholesterol, triglycerides, platelets and their phagocytic ability were measured twice. Postsurgical complications were assessed via Claven-Dindo classification.

Results:Group I-20 patients with an oral glutamine, Group II-38 patients received an intravenous glutamine. Group III-25 patients did not receive preoperative immunonutrition. 47\% patients Group I, 54\% patients Group II and 33\% patients Group III were malnourished. In Group I, percentage of phagocytizing platelet (\%PhP) was 1.1 pre- and 1.2 postoperatively. Phagocytic index (Phl) was 1.0 and 1.1. In Group II, \%PhP was 1.1 and 1.2. Phl was 1.0 and 1.1. In Group III \%PhP was 1.0 and1.2. Phl was 1.0 and 1.1. An increase in triglyceride level was observed in both immunonutrition groups. There was a fall in total protein, albumin level in Group II. In Group III there was a decline in total protein, albumin and cholesterol level. Total platelet count, and $\mathrm{Phl}$ was increased in both immunonutrition groups. There was also a rise in \%PhP in Group II. In Group III there was no change in blood plateles level, \%PhP and Phl. Complications rate was $53 \%$ in Group I, 29 \% in Group II, $40 \%$ in Group III.

Conclusions:In invasive gastric cancer, laboratory nutritional parameters are significantly reduced, causing malnutrition in $45.7 \%$ of patients. Oral glutamine supplementation inhibited the postoperative decline in protein metabolism parameters, however, this did not affect the reduction of the percentage of postoperative complications. Glutamine used preoperatively significantly reduced the percentage of serious surgical complications, regardless of the way it was supplemented. Patients with invasive gastric cancer have a significant decrease in platelet phagocytic activity. Immunonutrition based on intravenous form of glutamine allows to improve the phagocytic activity of platelets.

\section{Background:}

Gastric cancer incidence worldwide has declined significantly over the last 30 years. Nevertheless, it still constitutes a significant clinical problem. Only in 2015 stomach cancer caused 754000 deaths globally, which makes it fourth cancer-related mortality $[1,2]$. Despite progress in diagnostic and therapeutic management, therapy of invasive gastric cancer is associated with high morbidity rate and often low quality of life. Postoperative complication rate after total gastrectomy ranges from 9 to $47.5 \%$ and reported mortality rate varies between 1.1 and $10.8 \%$ [3-6]. Causes of poor outcomes are late diagnosis, pre-operative malnutrition and impaired immune system being one of the most important causes. Even eighty-five percent of patients undergoing surgery for gastric cancer are malnourished [7]. It is a result of 
tumour-related cachexia and decreased food intake due to anorexia. Moreover, host immune response is impaired [8]. The outcomes of cancer treatment can be optimised by maintaining an unharmed immune system and using immunogenic therapies to re-establish anti-tumour immune response. Glutamine plays a major role as a fuel source for macrophages, lymphocytes, and enterocytes. As the energy substrate for intestinal epithelial cells, it also protects the intestinal immune barrier against microbes.

Role of various blood cells in host response to cancer has been thoroughly investigated. Platelets (thrombocytes) are predominantly known for their role in coagulation. What is less commonly known is their ability to phagocytise, first reported by Mustard et al. in1968. These nonnuclear blood cells have the potential for chemotaxis and diapedesis [9]. They are able to phagocytise bacteria, viruses, antibody complexes, collagen and latex particles, working both as single platelets as well as in aggregates $[10,11]$. Upon activation, the thrombocyte changes its shape from discoid to an irregular one with numerous projections. This morphological change is accompanied by intensification of energetic processes and enhanced protein anabolism inside the activated platelet [12].

\section{Aim:}

The aim of the study was to determine the impact of preoperative glutamine-based immunonutrition on phagocytic activity of blood platelets in patients with gastric cancer. Effects of both, intravenous infusion of glutamine and oral supplementation, were assessed.

\section{Methods}

\section{Study population}

Patients with gastric cancer were enrolled in the study. The only inclusion criterion was an operable gastric cancer. The stage of gastric cancer was based on the TMN classification. Patients were divided into three randomized research groups. Group I and II was received preoperative glutamine-based immunonutrition, Group III did not receive preoperative immunonutrition. Patients receiving preoperative nutritional treatment were divided into two groups depending on the route of glutamine supply. Patients in Group I were fed a regular hospital diet enriched with an oral glutamine solution twice a day. Additionally, an infusion of three-chamber parenteral feeding bag (1447 mls) daily plus one ampoule of vitamins was administered. Group II was also on a regular diet supplemented with three-chamber parenteral feeding bag Smofkabiven Peripheral $(1447 \mathrm{mls})$ fortified with one ampoule of vitamins but also with an intravenous solution of glutamine $-100 \mathrm{ml}$ of $-\mathrm{N}(2)$-L-alanyl-L-glutamine dipeptide $(20 \mathrm{~g}$ $\mathrm{N}(2)$-L-alanyl-L-glutamine, $8.2 \mathrm{~g} \mathrm{~L}$ - alanyl and $13.46 \mathrm{~g} \mathrm{~L}$ - glutamine) with $0.2 \mathrm{~g} / \mathrm{ml}$ of the medicinal product. Group III was fed only by natural regular hospital diet supplemented with three-chamber parenteral feeding bag Smofkabiven Peripheral $(1447 \mathrm{mls})$ fortified with one ampoule of vitamins.

Exclusion criteria were inoperable gastric cancer and impaired gastric empting in the oral glutamine supply group. Due to the small number of early gastric cancer patients in clinical stage I were excluded 


\section{Data collection}

On admission to hospital, each patient was evaluated for nutritional status using SGA. The percentage of unintentional weight loss and BMI were calculated. Each patient had total protein, albumin, total cholesterol, triglyceride, platelet count and phagocytic activity assessed. Laboratory tests and phagocytic activity were reassessed 12 days after the surgery. Similar examination was performed in patients without preoperative immunonutrition.

In both groups, the duration of preoperative immunonutrition was 8 to 14 days (mean 12). Postoperative artificial nutrition without glutamine (three chamber bag + early postoperative enteral nutrition) was continued for 5-6 days after the surgery (mean 5.4) and it was the same in each group. Operation included stomach resection with excise of regional lymph nodes in the D2 range or above D2.

Nasojejunal feeding tube was placed intraoperatively. Early postoperative enteral nutrition with semielemental, normocaloric, low fat diet was started 20 hours post-surgery. Three patients with type 2 diabetes mellitus received a special diet normalizing glycaemia.

\section{Imaging technique and imaging analysis}

Phagocytic activity of blood platelets was determined against Staphylococcus aureus ATCC 653P bacterial strain, according to Mantur`s et al. method [13].

\section{Statistical analysis}

Results were compared to a control group with was consisted of 30 healthy individuals. The results were analysed using the Statistica 13.1 program, $p<0.05$.

The study has been approved by Bioethical Commission at Medical University of Bialystok No.: R-I022/149/2007.

\section{Results:}

Eighty-three patients with resectable invasive gastric cancer were recruited from the 2nd Department of General and Gastroenterological Surgery, Medical University of Bialystok from 2007 to 2015. There were 25 females (30\%) and 58 men (70\%) aged 27 to 84 (mean $63.5 \pm 14$ ). Patients were divided into three groups.

Distribution of clinical stages in particular groups is presented in Figure.

In Group I the percentage of invasive gastric cancer is $92 \%$, in Group II - 85\%, in Group III - 66\%. Early Gastric Cancer were detected in 3 patients of Group I, in 3 of Group II, and in 10 of Group III.

\section{Preoperatively}


Group I included 20 patients ( 7 women, 13 men) aged from 34 to 82 years $(65.2 \pm 11.9)$. Unintentional weight loss above $10 \%$ was demonstrated in patients 7 (35\%). Percentage of body weight ranged from 10 to $25 \%(15.3 \% \pm 6)$. Body mass index was from 16 to $28(26.3 \pm 7.29)$. Low protein level was found in 9 patients, in 16 patients a low albumin level. Lower triglyceride value was observed in 1 patient as well lower cholesterol level.

A preoperative level of total protein, albumin and triglyceride were significantly lover in comparison to control group. There was no statistically differences in total cholesterol level. Preoperative serum levels of total protein, albumin, cholesterol and triglyceride in patients of Group I are shown in Table 1. Malnutrition was found in $47 \%$ patients.

Table 1

Preoperative serum levels of total protein, albumin, cholesterol and triglyceride in patients of Group I in comparison to control

\begin{tabular}{|lccccc|}
\hline \multicolumn{1}{c}{ group. } \\
& Min & Max & Mean & SD & p \\
\hline & & & & & \\
\hline Total protein $(\mathrm{g} / \mathrm{dl})$ & 4.6 & 7.0 & 6.0 & 0.5 & 0.000 \\
\hline Albumin $(\mathrm{g} / \mathrm{dl})$ & 2.6 & 4.0 & 3.2 & 0.3 & 0.000 \\
\hline Cholesterol $(\mathrm{mg} / \mathrm{dl})$ & 102 & 232 & 159 & 32 & 0.153 \\
\hline Triglyceride $(\mathrm{mg} / \mathrm{dl})$ & 34 & 205 & 103 & 56 & 0.043 \\
\hline
\end{tabular}

No statistically differences of a total count of blood platelets in Group I and control group was observed. A preoperative phagocytic activity of blood platelets and phagocytic index were relevantly lover in comparison to healthy individuals. Preoperative phagocytic activity and phagocytic index are shown in Table 2.

Table 2

The number of blood platelets, the number of phagocytizing platelets, and phagocytic index in Group I before surgery in comparison to control group.

\begin{tabular}{|llllll|}
\hline & Min & Max & Mean & SD & p \\
\hline Platelets & 110000 & 450000 & 268500 & 84082.5 & 0.544 \\
Phagocytizing platelets & 1 & 1.2 & 1.1 & 0.1 & 0.000 \\
Phagocytic index & 1 & 1.1 & 1 & 0.1 & 0.000 \\
\hline
\end{tabular}

Group II consisted of 38 patients ( 8 women, 30 men) aged from 45 to 84 years $(66.9+10.4)$. Unintentional weight loss above $10 \%$ was demonstrated in 15 patients (50\%). Percentage of body weight 
ranged from 10 to $30 \%(15.7 \%+6.1)$. Body mass index was from 18 to $40(24+4.2)$. Low protein level was found in 17 patients, in 19 patients a low albumin level. Lower triglyceride value was observed in 1 patient. No patient had low cholesterol level. As in Group I the level of total protein, albumin and triglyceride were significantly lover in comparison to control group. There was no statistically differences in total cholesterol level. Preoperative serum levels of total protein, albumin, cholesterol and triglyceride in patients of Group II are shown in Table 3. Malnutrition was observed in 54\% patients.

Table 3

Preoperative serum levels of total protein, albumin, cholesterol and triglyceride in patients of Group II in comparison to control group.

\begin{tabular}{|lccccc|}
\hline & Min & Max & Mean & SD & P \\
\hline & & & & & \\
\hline Total protein $(\mathrm{g} / \mathrm{dl})$ & 5.3 & 8.0 & 6.1 & 0.6 & 0.000 \\
\hline Albumin $(\mathrm{g} / \mathrm{dl})$ & 1.9 & 4.0 & 3.4 & 0.5 & 0.000 \\
\hline Cholesterol $(\mathrm{mg} / \mathrm{dl})$ & 79 & 264 & 168 & 43 & 0.376 \\
\hline Triglyceride $(\mathrm{mg} / \mathrm{dl})$ & 37 & 175 & 102 & 37 & 0.015 \\
\hline
\end{tabular}

No statistically differences of a total count of blood platelets in Group II and control group was observed. A preoperative phagocytic activity of blood platelets and phagocytic index were relevantly lover in comparison to healthy individuals.

Preoperative number of total count of platelets, their phagocytic activity and phagocytic index are shown in Table 4.

Table 4

The number of blood platelets, the number of phagocytizing platelets, and phagocytic index in Group II before surgery in comparison to control group.

\begin{tabular}{|llllll|}
\hline & Min & Max & Mean & SD & p \\
\hline Platelets & 132000 & 532000 & 262111 & 104378 & 0.059 \\
\hline Phagocytizing platelets & 1 & 1.2 & 1.1 & 0.1 & 0.000 \\
\hline Phagocytic index & 0.8 & 1.1 & 1.0 & 0.1 & 0.000 \\
\hline
\end{tabular}

Group III consisted of 25 patients ( 10 women, 15 men) aged from 27 to 83 years $(63.5+13.8)$. Unintentional weight loss above $10 \%$ was demonstrated in 4 patients $(16 \%)$. Percentage of body weight ranged from 10 to $15 \%(12.5 \%+2.9)$. Body mass index was from 19 to $35(25.2+4.0)$. Low protein level was found in 5 patients, in 8 patients a low albumin level. No patient had low cholesterol and triglyceride 
level. As in previous groups the total protein, albumin and triglyceride level was relevantly lover in comparison to control group. There was also a statistical difference in cholesterol level. In $33 \%$ patients malnutrition was observed. Preoperative serum levels of total protein, albumin, cholesterol and triglyceride in patients of Group III are shown in Table 5. No statistically differences of a total count of blood platelets in Group III and control group was observed. A preoperative phagocytic activity of blood platelets and phagocytic index were relevantly lover in comparison to healthy individuals. The number of blood platelets, the number of phagocytizing platelets and phagocytic index in Group III before surgery are presented in Table 6.

Table 5

Preoperative serum levels of total protein, albumin, cholesterol and triglyceride in patients of Group III in comparison to control

\begin{tabular}{|lccccc|}
\hline \multicolumn{7}{c}{ group. } \\
& Min & Max & Mean & SD & P \\
\hline & & & & & \\
\hline Total protein $(\mathrm{g} / \mathrm{dl})$ & 5.3 & 7.0 & 6.4 & 0.6 & 0.002 \\
\hline Albumin $(\mathrm{g} / \mathrm{dl})$ & 2.7 & 5.0 & 3.6 & 0.4 & 0.000 \\
\hline Cholesterol $(\mathrm{mg} / \mathrm{dl})$ & 110 & 264 & 171 & 36 & 0.418 \\
\hline Triglyceride $(\mathrm{mg} / \mathrm{dl})$ & 31 & 197 & 100 & 36 & 0.001 \\
\hline
\end{tabular}

Table 6

The number of blood platelets, the number of phagocytizing platelets, and phagocytic index in Group III before surgery in comparison to control group.

\begin{tabular}{|llllll|}
\hline & Min & Max & Mean & SD & p \\
\hline Platelets & 98000 & 353000 & 233040 & 57866 & 0.303 \\
\hline Phagocytizing platelets & 0.9 & 1.2 & 1 & 0.1 & 0.000 \\
\hline Phagocytic index & 0.9 & 1.1 & 1 & 0.1 & 0.000 \\
\hline
\end{tabular}

\section{Postoperatively}

In Group I postoperatively a significant increase of triglyceride level was observed. There was no relevant changes in total protein, albumin and cholesterol levels.

Postoperative serum levels of total protein, albumin, cholesterol and triglyceride in patients of Group I are shown in Table 7. The total protein, albumin and triglyceride level did not change in relation to Group III. However a significant reduction in cholesterol level was found. 
Table 7

Postoperative serum levels of total protein, albumin, cholesterol and triglyceride in patients of Group I.

\begin{tabular}{|lccccc|}
\hline & Min & Max & Mean & SD & p \\
\hline & & & & & \\
\hline Total protein $(\mathrm{g} / \mathrm{dl})$ & 4.8 & 7.0 & 5.8 & 0.6 & 0.066 \\
\hline Albumin $(\mathrm{g} / \mathrm{dl})$ & 2.2 & 4.0 & 2.9 & 0.5 & 0.068 \\
\hline Cholesterol $(\mathrm{mg} / \mathrm{dl})$ & 84 & 195 & 153 & 30 & 0.398 \\
\hline Triglyceride $(\mathrm{mg} / \mathrm{dl})$ & 67 & 218 & 139 & 49 & 0.041 \\
\hline
\end{tabular}

A relevant increase of total count of platelets and index was noticed. There was no significant changes in phagocytic activity of blood platelets but phagocytic index was statistically increased. Postoperative total count of platelets, their phagocytic activity and phagocytic index are show in Table 8.

Table 8

The number of blood platelets, the number of phagocytizing platelets, and phagocytic index in Group I after surgery.

\begin{tabular}{|llllll|}
\hline & Min & Max & Mean & SD & P \\
\hline Platelets & 265000 & 1093000 & 657750 & 271598 & 0.018 \\
\hline Phagocytizing platelets & 1.1 & 1.3 & 1.2 & 0.1 & 0.068 \\
\hline Phagocytic index & 1 & 1.2 & 1.1 & 0.1 & 0.043 \\
\hline
\end{tabular}

In Group II a relevant fall in total protein, albumin, and cholesterol level was observed. There was no significant changes in triglyceride level in this group of patients.

Postoperative serum levels of total protein, albumin, cholesterol and triglyceride in patients of Group II are shown in Table 9. The total protein, albumin and cholesterol level did not change in comparison to Group III. There was a relevant increase in triglyceride level. There was a statistical increase in postoperative number of total count of platelets, their phagocytic activity and phagocytic index. Postoperative number of total count of platelets, their phagocytic activity and phagocytic index are shown in Table 10. 
Table 9

Postoperative serum levels of total protein, albumin, cholesterol and triglyceride in patients of Group II.

\begin{tabular}{|lccccc|}
\hline & Min & Max & Mean & SD & P \\
\hline & & & & & \\
\hline Total protein $(\mathrm{g} / \mathrm{dl})$ & 5.0 & 7.0 & 5.9 & 0.6 & 0.009 \\
\hline Albumin $(\mathrm{g} / \mathrm{dl})$ & 2.0 & 4.0 & 2.9 & 0.5 & 0.000 \\
\hline Cholesterol $(\mathrm{mg} / \mathrm{dl})$ & 78 & 212 & 143 & 33 & 0.000 \\
\hline Triglyceride $(\mathrm{mg} / \mathrm{dl})$ & 51 & 188 & 109 & 31 & 0.194 \\
\hline
\end{tabular}

Table 10

The number of blood platelets, the number of phagocytizing platelets, and phagocytic index in Group II after surgery.

\begin{tabular}{|llllll|}
\hline & Min & Max & Mean & SD & P \\
\hline Platelets & 180000 & 1152000 & 643368 & 288018 & 0.000 \\
\hline Phagocytizing platelets & 1 & 1.4 & 1.2 & 0.1 & 0.013 \\
\hline Phagocytic index & 0.8 & 1.2 & 1.1 & 0.1 & 0.024 \\
\hline
\end{tabular}

Group III - there was a relevant decline in total protein, albumin and cholesterol level in patients without immunonutrition. There was a significant rise in triglyceride level.

Postoperative serum levels of total protein, albumin, cholesterol and triglyceride in patients of Group III are shown in Table 11.

Table 11

Postoperative serum levels of total protein, albumin, cholesterol and triglyceride in patients of Group III.

\begin{tabular}{|lccccc|}
\hline & Min & Max & Mean & SD & P \\
\hline & & & & & \\
\hline Total protein $(\mathrm{g} / \mathrm{dl})$ & 4.4 & 7.0 & 5.9 & 0.7 & 0.192 \\
\hline Albumin $(\mathrm{g} / \mathrm{dl})$ & 1.9 & 4.0 & 2.9 & 0.5 & 0.009 \\
\hline Cholesterol $(\mathrm{mg} / \mathrm{dl})$ & 62 & 232 & 137 & 36 & 0.016 \\
\hline Triglyceride $(\mathrm{mg} / \mathrm{dl})$ & 56 & 243 & 138 & 52 & 0.037 \\
\hline
\end{tabular}


Postoperatively, the number of total blood platelets increased. There was no significant changes thrombocytes ability to phagocyte bacteria. Postoperative number of total count of platelets, their phagocytic activity and phagocytic index are shown in Table 12

\section{Table 12}

Table 11. The number of blood platelets, the number of phagocytizing platelets, and phagocytic index in Group III after surgery.

\begin{tabular}{|llllll|}
\hline & Min & Max & Mean & SD & P \\
\hline Platelets & 123000 & 1189000 & 564416 & 320658 & 0.050 \\
\hline Phagocytizing platelets & 1 & 1.4 & 1.2 & 0.1 & 0.059 \\
\hline Phagocytic index & 0.9 & 1.1 & 1.1 & 0.1 & 0.075 \\
\hline
\end{tabular}

\section{Complications}

In Group I overall postoperative complication rate was $53 \%$ with major complications of $33 \%$. 30-day mortality was $12 \%$.

In Group II overall postoperative complication rate was $29 \%$ with major complications of $40 \%$. 30 -day mortality was $6 \%$.

In Group III overall postoperative complication rate was $40 \%$ with major complications of $83 \%$. 30 -day mortality was $6 \%$.

Table 13. shows surgical complications in examined groups according to Clavien-Dindo classification.

Table 13

Postoperative complications in both

groups according to Clavien-Dindo

classification (14).

\begin{tabular}{|llll|}
\hline Grade & Group I & Group II & Group III \\
\hline I & 1 & 2 & - \\
\hline IIIla & 5 & 5 & - \\
\hline IIIb & - & 1 & 1 \\
\hline IVa & 1 & 1 & 1 \\
\hline IVb & - & 1 & 2 \\
\hline $\mathrm{V}$ & 2 & 2 & 1 \\
\hline
\end{tabular}

Page 10/19 


\section{Dicussion:}

Different surgical techniques have various local and general imbroglios [6]. One of the most important problem in the treatment of patients suffering from stomach cancer is their proper preoperative preparation. Malignancy process is associated with malnutrition, as well as with impairment of the host immune defence. Furthermore, the increase in energy-protein expenditure during the surgery increases malnutrition and exacerbates the risk of perioperative complications. Excessive loss of protein and energy observed in patients with advanced cancer is associated with increased morbidity, poor response to chemotherapy and a shorter survival time [15]. Li et al. reported cachexia in $73.3 \%$ of patients with gastric cancer [16]. Even prolonged malnutrition during early life may increase the risk of stomach cancer mortality in later life [17]. Hence nutritional status needs to be optimised in the preoperative period. Fukuda et al. analysed 800 gastric cancer patients who had undergone gastrectomy. They classified 19\% patients as a malnourished. In multivariate analysis malnutrition was independent factor postoperative fewer infections. Based on the assessment of nutritional status based on biochemical analysis, malnutrition was found in $47 \%$ patients in Group I, $54 \%$ patients in Group II, $33 \%$ patients in Group III. Well-managed preoperative nutritional support decreased

the incidence of postoperative surgical site infections [18]. The current ESPEN guidelines recommends about a 10-14 day period of feeding with immunologically active compounds [19]. In the present study, malnutrition has also been reported. Unintentional weight loss above $10 \%$ of body weight in last 6 months was found in $34 \%$ patients. The main unintentional weight loss was $13.7 \mathrm{~kg}$. Biochemical analysis shown similar values of examined parameters in all groups of patients.

In Group I low protein level was found in 9 patients, in 16 patients a low albumin level. Lower triglyceride value was observed in 1 patient as well lower cholesterol level. In Group II low protein level was found in 17 patients, in 19 patients a low albumin level. Lower triglyceride value was observed in 1 patient. No patient had low cholesterol level. As in previous groups in group without immunonutrition the total protein, albumin and triglyceride level was relevantly lover in comparison to control group. There was also a statistical difference in cholesterol level. It was found that in all patients, body mass index correlated with an unintentional weight loss and serum albumin concentrations. Moreover, the percentage of unintentional weight loss negatively correlated with total preoperative protein and triglyceride levels. Furthermore, total protein concentration was positively correlated with albumin concentration and triglycerides. Liu et al found that preoperative BMI was positively correlated with albumin and triglyceride levels and preoperative albumin levels were positively correlated with triglycerides. Therefore, serum albumin level is not only a window into the patients' nutritional status but is also a useful factor for predicting prognosis [20]. Poor survival was also observed in gastric cancer patients with lower levels of $\mathrm{BMI}$, albumin, and triglyceride [21]. Because low levels of serum albumin are associated with poor outcomes in cancer patients, they can be used as an independent indicator when assessing the need for aggressive nutritional intervention [22].

Glutamine-supplemented perioperative nutrition has been investigated in patients with

Page $11 / 19$ 
a variety of diseases but the effects have not been conclusively established [23]. In our study, interesting results in two different models of preoperative immunonutrition were observed.

In Group I the increased triglyceride level was observed. In Group II the total protein, albumin and cholesterol level was declined. In Group III both groups the decreased total protein after the surgery was noticed but albumin level was similar before and after surgery.

In Group I the total protein, albumin and triglyceride level did not change in relation to Group III. However a significant reduction in cholesterol level was found. In Group II The total protein, albumin and cholesterol level did not change in comparison to Group III. There was a relevant increase in triglyceride level.

We can say that glutamine using during preoperative immunonutrition helped to sustain higher albumin levels whilst on the other hand, a decrease in total protein level was recorded. Tue et al have also observed an improvement in postoperative cumulative nitrogen balance with perioperative parenteral nutrition supplemented with glutamine in patients undergoing abdominal surgery [24]. One explanation for this protein metabolism may be a reduced production of proinflammatory cytokines. In a previous study of our group, we found elevated levels of interleukin 6 (IL-6) in gastric cancer patients which correlated negatively with the disease stage. Its values were highest in patients with early gastric cancer [25]. Administration of the preoperative parenteral glutamine immunonutrition results in normalization of cholesterol and triglycerides by increasing or decreasing their levels to achieve the normal range. In oral glutamine supplementation model, there were no significant changes in total protein, albumin and cholesterol levels. Glutamine enriched nutrition support in surgical patient's remains controversial. The meta-analysis thirteen randomized controlled trials showed improving immune function, reducing incidence of infectious complications and shortening the length of hospital stay [26]. Jiang et al noticed alanyl-glutamine supplemented parenteral nutrition clinically safe with better nitrogen balance, and maintained intestinal permeability in postoperative patients than patients who received isonitrogenous and isocaloric parenteral nutrition [27]. The highest percentage of postoperative complications was found in Group I and it was almost twice as high compared to patients in Group II. Perhaps this is due to the different numbers of patients. However, an interesting result is a similar percentage of severe complications in both groups with preoperative immunonutrition. Major postoperative complications were almost three times more common in patients without preoperative immunonutrition. Giannotti et al did not report better surgery outcomes with parenteral glutamine supplementation in well-nourished patients with gastrointestinal cancer [28].

High number and wide distribution within the circulatory system make thrombocytes

an important component of immune system but their role in immune response is not yet fully understood. Platelet granules contain: peroxidase, acid phosphatase, cationic proteins

and proteolytic enzymes. These substances represent high activity for bacteria phagocytosis. Furthermore, platelets exert cytotoxic effects on cancer cells by adhering to them via antigenic determinants. Then characteristic structural changes, such as Golgi apparatus hypertrophy, increase in 
secretory granulations and displacing them towards contact zone with a neoplastic cell are observed. Platelet cytotoxicity ensues from their ability to product and release lytic mediators [29]. Additionally, platelets play an important role in tumour metastasis. Platelet-delivered proteolytic enzymes facilitate the release and migration of tumour cells across

the vessel wall [30]. Furthermore, activated platelets release substances which increase vascular permeability, factors stimulating myocytes proliferation, platelet activating factor, prostaglandins, histamine and serotonin. The substances above facilitate an implantation

and growth of metastatic tumour [31]. In our last studies we found that the fraction of phagocytizing platelets and their phagocytic index in gastric cancer patients was markedly impaired as compared to healthy individuals [32]. Current work confirms impaired phagocytic activity in patients with gastric cancer. A decreased phagocytic activity can influence inflammatory processes as well as cancer growth [25]. In this study, impact of immunonutrition on phagocytic activity of platelets was evaluated. Glutamine is an essential amino acid for fast-dividing immune cells, epithelial cells of the gastrointestinal tract, fibroblasts and reticulocytes. It is a precursor of protein and nucleotide synthesis, it is also involved in hepatic gluconeogenesis and glutathione synthesis. Its high concentration was found in the intestinal mucosa cells. Glutamine and glutamate are amino acids responsible for the transport of nitrogen and detoxification of ammonia. The consequence of inhibition of glutathione synthesis is mucosal destruction, diarrhoea, and growth inhibition. Parenteral supplementation of glutamine in rats demonstrated its protective role against bacterial translocation [33]. Glutamine impact on blood platelets phagocytic activity is unknown.

In our study in all groups showed severe impairment of thrombocyte phagocytic activity. The significant decline in phagocytic activity of blood platelets and their phagocytic index in all patients was observed. In patients with oral glutamine supplementation the percentage of blood platelets and their phagocytic index was increased. In patients with intravenous glutamine administration both total count of platelets, their phagocytic activity and index was improved. There was no improvement in platelet phagocytic activity in patients without immunonutrition.

Authors had previously reported partial improved thrombocyte phagocytic activity in gastric cancer patients as a result of perioperative immunonutrition enriched with glutamine and $\omega-3$ fatty acids both in local disease and in peritoneal dissemination [32] but this is the first study analysing blood platelets phagocytic activity in gastric cancer patients receiving enteral glutamine diet preoperatively.

\section{Conclusions:}

In invasive gastric cancer, laboratory nutritional parameters are significantly reduced, causing malnutrition in $45.7 \%$ of patients. Oral glutamine supplementation used in preoperative nutritional therapy inhibited the postoperative decline in protein metabolism parameters, however, this did not affect the reduction of the percentage of postoperative complications. Glutamine used in preoperative immunonutrition significantly reduced the percentage of serious surgical complications, regardless of the 
way it was supplemented. Patients with invasive gastric cancer have a significant decrease in platelet phagocytic activity. Immunonutrition based on intravenous form of glutamine allows to improve the phagocytic activity of platelets.

\section{Abbreviations}

SGA-Subjective Global Assessment

BMI-Body Mass Index

TNM- Classification of Malignant Tumours

PhIT-phagocytic index

PhT\%-percentage of phagocytizing thrombocytes

ESPEN- European Society for Clinical Nutrition and Metabolism

\section{Declarations}

Trial has been registered with Clinicaltrials.gov - NCT01704664 registered October 11.2012,

Title of registration: Perioperative Immunonutrition, Phagocytic and Bactericidal Activity of Blood Platelets in Gastric Cancer Patients

URL: https://clinicaltrials.gov/ct2/show/NCT01704664?

term $=$ NCT01704664\&cond=Gastric + Cancer\&draw $=2 \&$ rank $=1$

\section{Acknowledgements}

Authors want to thank Medical University of Bialystok for financial support. All authors want to thank patients who took part in this study.

\section{Authors Contributions}

All authors have read and approved the manuscript.

ZK concept and design of study, interpretation of data, finalizing manuscript, JMK assessment of blood platelets phagocytic activity, AJ interpretation data and preparing manuscript, AM statistical data, AK interpretation data, preparing manuscript, fluent in English edition, BK design of study.

\section{Funding}

The research was funded by Medical University of Bialystok. Research number: N/ST/ZB/17/001/1137. 


\section{Availability of data and material}

The raw data generated and analysed in the current study are not publicly available due to appropriate protection of patient personal information but are available from the corresponding author on reasonable request.

\section{Ethics approval and consent to participate}

All procedures followed were in accordance with the ethical standards of the responsible committee on human experimentation (institutional and national) and with the Helsinki Declaration of 1964 and later versions. Informed consent to be included in the study, or the equivalent, was obtained from all patients. Informed consent obtained from study participants was in written form.

\section{Consent to Publish}

Not Applicable.

\section{Competing Interests}

The authors declare that they have no conflict of interest.

\section{Authors details}

- Second Department of General and Gastroenterological Surgery, Medical University of Bialystok, Poland

- Department of Clinical Laboratory Diagnostics, Medical University of Bialystok, Poland

- Department of Statistic and Medical Informatics, Medical University of Bialystok, Poland

- Department of Investigative Medicine, Imperial College London, United Kingdom

\section{References}

1. WHO. Cancer: Fact sheet; 2017.

2. Balakrishnan M, Rollin G, Ashish S, Graham DY. Changing Trends in Stomach Cancer Throughout the World. Curr Gastroenterol Rep 2017; 19:36. DOI: 10.1007/s11894-017-0575-8

3. Papenfuss W, Kukar M, Oxenberg J, Attwood K, Nurkin S, Malhirta U et al. Morbidity and Mortality Associated with Gastrectomy for Gastric Cancer. Ann Surg Oncol 2014; 21:3008-14. DOI: 10.1245/s10434-014-3664-z

4. Selby LV, Vertosick EA, Sjoberg DD, Schattner MA, Janjigian YY, Brennan MF et al. Morbidity after total gastrectomy. Analisys of 23 patients. J Am Coll Surg 2015; 220(5):863-71. DOI: 10.1007/s11605-016-3195-y

5. Dhir M, Smith LM, Ullrich F, Leiphrakpam PD, Ly QP, Sasso AR, et al. Preoperative Nomogram to Predict Risk of Perioperative Mortality Following Gastric Resections for Malignancy. J Gastrointest 
Surg 2012; 16(11):2026-36. DOI: 10.1007/s11605-012-2010-7

6. McKenzie Stancu S, Popescu B. A comprarative Analysis of Immediate Postoperative Compliations Following Total Gastrectomy. Pol Przegl Chir; 89(3).

7. Young-Gil S, In GK, Seung WR. Assessment of nutritional status in laparoscopic gastrectomy for gastric cancerTransl Gastroenterol Hepatol. 2017; 2: 85. Published online 2017 Oct 28. DOI: 10.21037/tgh.2017.09.08

8. Peng LS, Zhang JY, Teng YS, Zhao YL, Wang TT, Mao FY et al. Assessment of nutritional status in laparoscopic gastrectomy for gastric cancer. Cancer Immunol Res. 2017 Mar;5(3):248-256. DOI: 10.1158/2326-6066.

9. Mustard JF PMA. Platelet phagocytosis. Sem Haematol 1968; 2:164-84.

10. Clawson CC WJG. Platelet Interaction with Bacteria. I. Reaction Phases and Effects on Inhibitors. Am J Pathol 1971; 65(2):367-80.

11. Kemona H, Andrzejewska A, Prokopowicz J, Nowak H, Mantur M. Phagocytic activity of human blood platelets examined by electron microscopy. Folia Haematol Int Mag Klin Morphol Blutforsch 1986; 113(5):696-702.

12. Bessler $H$, Agam G, Djaldetti M. Increased protein synthesis by human platelets during phagocytosis of latex particles in vitro. Tromb Haemost 1976; Apr 30;35(2):350-7.

13. Mantur M, Wołosowicz N, Prokopowicz J, Kemona H. System for testing the phagocytosis capacity of human blood platelets. Folia Haematol Int Mag Klin Morphol Blutforsch 1986; 113(5):685-9.

14. Dindo D, Demartines N, Clavien PA. Classification of Surgical Complications. A New Proposal with Evaluation in a Cohort of 6336 Patients and Results of a Survey. Ann Surg. 2004 Aug; 240(2): 205213. DOI: 10.1097/01.sla.0000133083.54934.ae

15. Slaviero KA, Read JA, Clark SJ, Rivory LP. Baseline nutritional assessment in advanced cancer patients receiving palliative chemotherapy. Nutritional and cancer 2003; 46:148-57. DOI: 10.1207/S15327914NC4602_07

16. Li H, Li Y, Liu Y, Huang D, Bai M, Deng SGT et al. The incidence and impact of weight loss with cachexia in gastric cancer patients. J of Clin Oncol. DOI: 10.1200/jco.2015.33.15_suppl.e20644

17. Li QD, Li H, Li FJ, Wang MS, Li ZJ, Han J et al. Nutrition deficiency increases the risk of stomach cancer mortality. BMC Cancer 2012; Jul 28;12:315. DOI: 10.1186/1471-2407-12-315.

18. Fukuda Y., Yamamoto K., Hirao M., Nishikawa K., Maeda S., Haraquchi N. et al. Prevalence of Malnutrition Among Gastric Cancer Patients Undergoing Gastrectomy and Optimal Preoperative Nutritional Support for Preventing Surgical Site Infections. Ann Surg Oncol 2015; Dec: 22 Suppl 3:778-85. DOI: 10.1245/s10434-015-4820-9.

19. Arends J, Bachmann P, Baracos V, Barthelemy N, Bertz H, Bozzetti F, et al. ESPEN guidelines on nutrition in cancer patients. Clinical nutrition 2017; 36(1):11-48. DOI: 10.1016/j.clnu.2016.07.015

20. Lien YC, Hsieh CC, Wu YC, Hsu HS, Hsu WH, Wang LS et al. Preoperative serum albumin level is a prognostic indicator for adenocarcinoma of the gastric cardia. J Gastrointest Surg 2004; 8:1041-8. 
DOI: 10.1016/j.gassur.2004.09.033

21. Lis CG, Grutsch JF, Vashi PG, Lammersfeld CA. Is serum albumin an independent predictor of survival in patients with breast cancer? JPEN J Parenter Enteral Nutr 2003; 7:10-5. DOI:

$10.1177 / 014860710302700110$

22. Liu BZ, Tao L, Chen YZ, Li XZ, Dong YL, Ma YJ et al. Preoperative Body Mass Index, Blood Albumin and Triglycerides Predict Survival for Patients with Gastric Cancer. PLoS One 2016; 11(6). DOI: 10.1371/journal.pone.0157401

23. Yue C, Tian W, Wang W, Huang Q, Zhao R, Zhao Y et al. The Impact of Perioperative Glutaminesupplemented Parenteral Nutrition on Outcomes of Patients Undergoing Abdominal Surgery: A Metaanalysis of Randomized Clinical Trials. Am Surg 2013; 79(5):506-13. DOI: 10.1186/s12937-0160188-3

24. Jo S, Choi SH, Kim EM, MIN MS, Choi DW, Seo JM et al. Missing Effect of Glutamine Supplementation on the Surgical Outcome after Pancreaticoduodenectomy for Periampullary Tumors: A Prospective, Randomized, Double-blind, Controlled Clinical Trial. World J Surg 2006; 30(11):1983-4. DOI: 10.1007/s00268-005-0678-5

25. Matowicka-Karna J, Kamocki Z, Kemona H. Assessment of platelet activation and phagocytic activity in gastric cancer patients. World J Gastrointest Pathophysiol 2013; 15;4(1):12-7. DOI: 10.4291/wjgp.v4.i1.12

26. Kai K, Xiao-Liang S, Yong-Sheng Z, Xian-Li L, Jian Z. Effect of Glutamine Enriched Nutrition Support on Surgical Patients with Gastrointestinal Tumor: A Meta-Analysis of Randomized Controlled Trials. Chin Med J (Engl). 2015 Jan 20; 128(2): 245-251. DOI: 10.4103/0366-6999.149219

27. Jian ZM, Cao JD, Zhu WX, Yu JC, Ma EL, Wang XR et al. The Impact of Alanyl-Glutamine on Clinical Safety, Nitrogen Balance, Intestinal Permeability, and Clinical Outcome in Postoperative Patients: A Randomized, Double-Blind, Controlled Study of 120 patients. JPEN J Parenter Enteral Nutr 1999; 23(5 suppl):62-6.

28. Gianotti L, Braga M, Bozzetti F, Mariani L. Perioperative intravenous glutamine supplemetation in major abdominal surgery for cancer: a randomized multicenter trial. Ann Surg 2009; 250(5):684-90. DOI: 10.1097/SLA.0b013e3181bcb28d.

29. Bykovskaya SN, Bolvacheva AV, Kisselevsky MV, Khaylenko VA, Bykovsky AF. Platelet-mediated cytotoxicity and its enhancement by platelet activating factor. Biomed Pharmacother 1991; 45:27988.

30. Metha P. Potential role of platelets in the pathogenesis of tumor methastasis. Blood 1984; Jan;63(1):55-63.

31. Hara Y, Steiner M, Baldini MG. Platelets as an source on growth promoting factors for tumor cells. Cancer res 1980.

32. Kamocki ZK, Matowicka-Karna J, Szynaka B, Kedra B, Kemona H. Effects of perioperative immunostimulating nutritional therapy of the phagocytic activity of blood platelets in patients with various clinical stages of gastric cancer. Adv Med Sci 2013; 58(2). DOI: 10.2478/ams-2013-0028. 
33. Burke DJ, Alverdy JC, Aoys E, Moss GS. Glutamine-supplemented total parenteral nutrition improves gut immune function. Arch Surg 1989; 124:1396-9

\section{Figures}

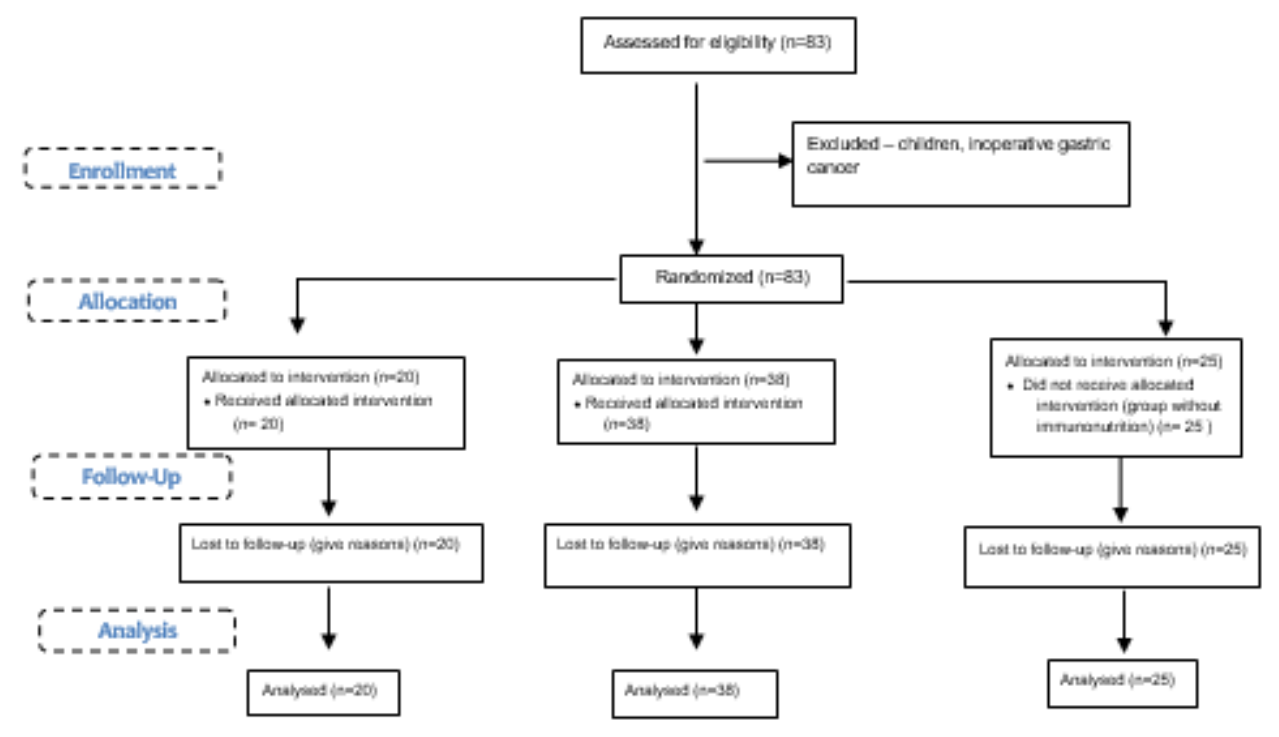

Figure 1

Clinical stages of Gastric Cancer in examined particular groups of patients

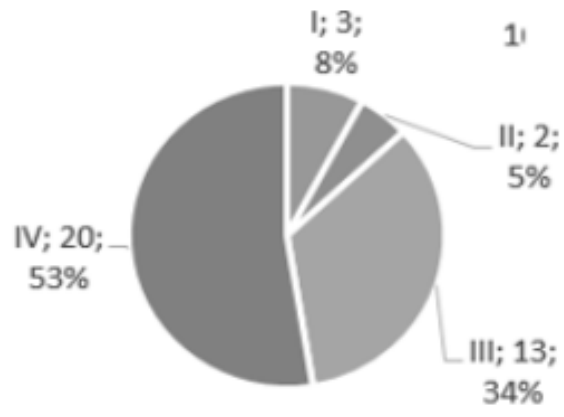

Group I N = 20

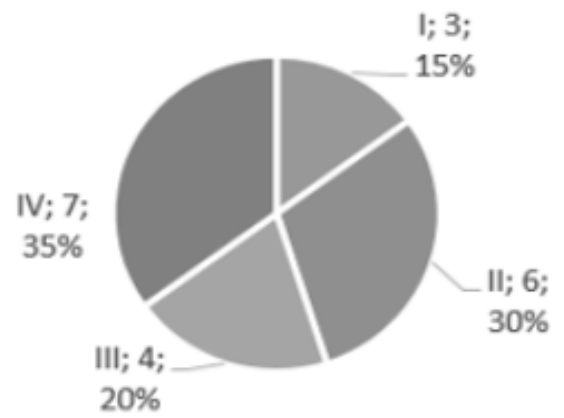

Group II N $=38$

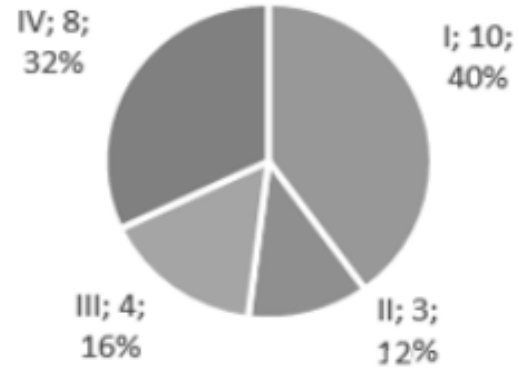

Group III N = 25

Figure 2

Clinical stages of Gastric Cancer in examined particular groups of patients 
This is a list of supplementary files associated with this preprint. Click to download.

- CONSORT2010Checklist.doc 